\title{
Faktor-Faktor yang Berhubungan dengan Partisipasi Petani dalam Kegiatan Unit Pengolah Pupuk Organik (Uppo) di Kabupaten Karanganyar
}

\section{Factors Related to Farmers' Participation in Activity of Organic Fertilizer Processor Unit or Unit Pengolah Pupuk Organik (Uppo), Karanganyar Regency}

\author{
Oky Dea Novianti', Dwiningtyas Padmaningrum² ${ }^{2}$, Agung Wibowo ${ }^{3}$ \\ Program Studi Penyuluhan dan Komunikasi Pertanian Fakultas Pertanian \\ Universitas Sebelas Maret \\ J1. Ir. Sutami No.36 A Kentingan Surakarta 57126 Telp/Fax (0271) 637457 \\ Email: okydean@student.uns.ac.id
}

\begin{abstract}
Farmers' participation shows farmers' involvement and partnership in agriculturewhich include activities of planning, implementing, and utilizing the results of a development program done by local communities. Objectivesof this research were analysing: (1) farmers' participation in program of Organic Fertilizer Processor Unit or Unit Pengolah Pupuk Organik (UPPO); (2) age, individual's experience, non-formal education, information access, and farmers' risk taking in UPPO; and (3) correlation between age, individual's experience, non-formal education, information access, and farmers' risk taking with participation in UPPO. Basic method of the research was quantitative method with survey technique. Area determination was intentionally decided, the areas that ran UPPO in six villages from five sub-districts, consisting of Pereng and Pendem Villages (Mojogedang Sub-district); Seloromo Village (Jenawi Sub-district), Ngeblak Village (Tawangmangu Sub-district); Kerjo Village (Kerjo Subdistrict); Ngadiluwih Village (Matesih Sub-district) in Karanganyar Regency. The sampling technique used proportional random sampling that involved sixty respondents. The analysis data used correlation test of Rank Spearman $\left(\mathrm{r}_{\mathrm{s}}\right)$ with program of IBM SPSS 22.0. The research result showed that: (1) farmers' participation in UPPO were included as high category. (2) age included as productive category, individual's experience included as high category, non-formal education as high category, information access in low category, risk taking included as prepared category. (3) there was significant correlation between individual's experience, information access, and taking farmers' risk with farmers' participation in UPPO, however there was not significant correlation between farmers' age and non-formal education with farmers' participation in UPPO.
\end{abstract}

\section{Keywords : Organic Farming, Organic Fertilizer, Participation, Unit Pengolah Pupuk Organik (Uppo)}

Abstrak: Partisipasi petani menunjukkan keterlibatan dan keikutsertaan petani dalam pembangunan yang meliputi kegiatan dalam perencanaan, pelaksanaan dan pemanfaatan hasil suatu program pembangunan yang dikerjakan masyarakat lokal. Penelitian ini bertujuan menganalisis: (1) partisipasi petani dalam kegiatan Unit Pengolah Pupuk Organik (UPPO); (2) umur, pengalaman individu, pendidikan nonformal, akses informasi dan pengambilan risiko petani dalam pemanfaatan UPPO; dan (3) hubungan antara umur, pengalaman individu, pendidikan nonformal, akses informasi dan pengambilan risiko petani dengan partisipasi dalam kegiatan UPPO. Metode dasar penelitian adalah kuantitatif dengan teknik survai. Penentuan lokasi ditentukan secara sengaja yakni wilayah yang menjalankan kegiatan UPPO di 6 desa dari 5 kecamatan, meliputi Desa Pereng dan Desa Pendem (Kecamatan Mojogedang); Desa Seloromo (Kecamatan Jenawi); Desa Ngeblak (Kecamatan Tawangmangu); Desa Kerjo (Kecamatan Kerjo); serta Desa Ngadiluwih (Kecamatan Matesih) di Kabupaten Karanganyar. Teknik pengambilan sampel menggunakan teknik proportional random sampling yang melibatkan 60 responden. Analisis data menggunakan uji korelasi rank spearman $\left(\mathrm{r}_{\mathrm{s}}\right)$ dengan program IBM SPSS 22.0. Hasil penelitian menunjukkan bahwa: (1) petani memiliki partisipasi tinggi dalam kegiatan UPPO, (2) mayoritas petani berumur produktif, mayoritas pengalaman individu petani termasuk kategori tinggi, mayoritas pendidikan nonformal petani termasuk kategori tinggi, petani memiliki akses informasi rendah, mayoritas petani siap dalam pengambilan risiko, (3) terdapat hubungan yang sangat signifikan antara pengalaman individu, akses informasi dan pengambilan risiko petani dengan partisipasi petani dalam kegiatan UPPO, namun tidak terdapat hubungan yang signifikan antara umur petani dan pendidikan nonformal dengan partisipasi petani dalam kegiatan UPPO.

Kata Kunci: Partisipasi, Pertanian Organik, Pupuk Organik, Unit Pengolah Pupuk Organik (Uppo) 


\section{PENDAHULUAN}

Permentan No.64 Tahun 2013, menyebutkan bahwa pertanian organik menekankan pada penerapan praktek manajemen yangmengutamakanpenggunaan input dari limbah kegiatan budidaya di lahan. Tujuan utama dari pertanian organik adalah mengoptimalkan kesehatan dan produktivitas kehidupan di tanah, tumbuhan, hewan dan manusia (Prawoto dan Surono, 2005). Pertanianorganikyangberkelanjutan diwujudkan dengan adanya penataan ruang melalui perencanaan sarana dan prasarana utama dan pendukung produksi pertanian beras organik (Dirjen Tanaman Pangan, 2018). Upaya pemerintah untuk mendukung petani dalam menyediakan pupuk organik secara mandiri yaitu dengan memfasilitasi kegiatan pengembangan Unit Pengolah Pupuk Organik (UPPO). Melalui kegiatan UPPO, diharapkan petani dapat memproduksi dan menggunakan pupuk organik secara insitu. Sasaran UPPO adalah daerah yang memiliki potensi sumber bahan baku pembuatan kompos, terutama produk samping tanaman organik, kotoran ternak dan sampah organik rumah tangga pada sub sektor tanaman pangan, hortikultura, perkebunan rakyat dan peternakan (Kementan, 2018).

Salah satu daerah yang memiliki kebijakan pertanian organik adalah Kabupaten Karanganyar. Keputusan Bupati No. 050/727 Tahun 2016, beras organik menjadi komoditas unggulan kawasan dan sebagai komoditas pendukung adalah pupuk organik.Kawasan ini mayoritas masyarakat bermatapencaharian sebagai petani dan setiap kepala keluarga rata-rata memiliki satu sampai dua ekor sapi sebagai hewan ternak, namun potensi ini belum di imbangi dengan wawasan dan penguasaan teknologi pertanian organik. Produksi beras organik di kawasan ini masih belum memenuhi permintaan pasar akan pupuk dan beras organik (RPKP Kabupaten Karanganyar, 2016). Mengacu pada Kementan (2016) strategi yang dilakukan untuk mencapai sasaran pembangunan kawasan perdesaan organik adalah dengan meningkatkan aksesibilitas pasar dan informasi beras organik, meningkatkan kapasitas dan kualitas sumber daya manusia, dan meningkatkan produktivitas beras organik. Kegiatan UPPO di Kabupaten Karanganyar diharapkan mampu mendukung pengembangan beras organik di wilayah ini, melalui peningkatan sarana produksi pupuk organik dan efektivitas produksi, meningkatkan efektivitas proses produksi on-farm dan pascapanen, serta meningkatkan sarana produksi pupuk organik.

Keterlibatan masyarakat dalam UPPO idealnya perlu dilakukan secara maksimal. Salah satu faktor keberhasilan program ini juga dapat ditentukan oleh partisipasi dari petani yang menjadi sasaran utama program. Pentingnya partisipasi masyarakat merupakan suatu alat guna memperoleh informasi mengenai kondisi, kebutuhan, dan sikap masyarakat setempat yang tanpa kehadirannya program pembangunan serta proyek-proyek akan gagal, oleh karena itu masyarakat harus telibat mulai dari perencanaan hingga evaluasi (Haqqie, 2016). Melalui partisipasi masyarakat, diharapkan program UPPO mampu memberikan solusi terhadap ketersediaan pupuk organik secara mandiri dan berkelanjutan dan menjadi sarana pendukung dalam pengembangan kawasan perdesaan organik di Kabupaten Karanganyar. Berdasarkan uraian diatas dapat dijelaskan beberapa permasalahan yang akan dikaji dalam penelitian mengenai faktor-faktor yang berhubungan dengan partisipasi petani dalam kegiatan Unit Pengolah Pupuk Organik (UPPO) di Kabupaten Karanganyar, diantaranya yakni menganalisis; (1) partisipasi petani dalam kegiatan UPPO di Kabupaten Karanganyar, (2) umur, pengalaman individu, pendidikan nonformal, akses informasi dan pengambilan risiko petani dalam kegiatan UPPO di Kabupaten Karanganyar, (3) hubungan antara umur, pengalaman individu, pendidikan nonformal, akses informasi dan pengambilan risiko petani dengan partisipasi petani dalam kegiatan UPPO di Kabupaten Karanganyar.

Undang-undang Nomor 32 Tahun 2009 tentang perlindungan dan pengelolaan lingkungan hidup, pembangunan berkelanjutan diartikan sebagai upaya sadar dan terencana yang memadukan aspek lingkungan hidup, sosial, dan ekonomi ke dalam strategi pembangunan untuk menjamin keutuhan lingkungan hidup. Partisipasi masyarakat merupakan suatu teknis untuk memberikan kesempatan dan wewenang kepada masyarakat secara bersama, dalam memecahkan persoalan (Bappenas, 2007). Partisipasi anggota masyarakat adalah keterlibatan 
anggota masyarakat dalam pembangunan meliputi kegiatan dalam perencanaan dan pelaksanaan (implementasi) program pembangunan yang di kerjakan di masyarakat lokal (Adisasmita, 2013). Slamet (1993) menjelaskan 3 bentuk tahapan partisipasi yakni perencanaan, pelaksanaan, dan pemanfaatan hasil.

Faktor-Faktor Partisipasi yang dikaji yakni Umur petani menurut Bachtiar (1991) disebutkan bahwa akan mempengaruhi kemampuan fisik dan respon terhadap hal-hal yang baru dalam menjalankan usahataninya. Menurut Molo dkk (2003) umur responden dapat mempengaruhi kecepatan petani dalam menerapkan teknologi budidaya tanaman pertanian yang baru. Pengalaman Individu, seseorang yang mempunyai pengalaman yang lebih lama akan mempunyai keterampilan yang lebih tinggi, sehingga produktivitasnya pun lebih tinggi dibandingkan dengan tenaga kerja yang baru memiliki sedikit pengalaman (Sulaeman, 2014). Pendidikan nonformal adalah pendidikan yang dilakukan secara teratur, dengan sadar dilakukan tetapi tidak terlalu ketat mengikuti peraturan-peraturan yang ada (Joesoef, 2008). Akses informasi merupakan akses terhadap struktur fisik yang mengandung informasi, struktur elektronik yang berisi informasi, dan panduan dalam memperoleh informasi (Shanonn, 2010). Pengambilan Risiko adalah suatu kejadian dimana hasil dari kejadian dan peluang terjadinya bisa diketahui (Debertin 1986). Risiko juga dapat diartikan suatu kegagalan atau ketidakberhasilan dalam menangkap peluang usaha.Bentuk risiko usaha itu dapatberupa kerugian finansial dan pengalaman buruk (Basrowi, 2014). Penelitian ini penting dilakukan, karena partisipasi merupakan prinsip dasar dari pengembangan masyarakat. Keikutsertaan masyarakat dalam pelaksanaan pembangunan secara aktif baik pada pembuatan rencana pelaksanaan maupun penilaian pembangunan menjadi demikian penting sebagai tolok ukur kemampuan masyarakat untuk berinisiatif dan menikmati hasil dan pembangunan yang telah dilakukan.

\section{METODE PENELITIAN}

Penelitian ini menggunakan metode penelitian kuantitatif yaitu metode penelitian yang berlandaskan pada filsafat positivistik atau suatu asumsi bahwa suatu gejala dapat diklasifikasikan, dan pengaruh gejala bersifat sebab akibat (Sugiyono, 2014). Pemilihan Kabupaten Karanganyar sebagai lokasi penelitian ditentukan secara sengaja (purposive) sesuai surat keputusan Bupati No. 050/727 Tahun 2016 Kabupaten Karanganyar dijadikan lokasi pengembangan kawasan perdesaan beras organik di lereng Gunung Lawu. Kabupaten Karanganyar menjadi wilayah yang memiliki potensi dalam sektor peternakan yang fokus pada pemberdayaan serta produktivitas pupuk organik (RPKP Kabupaten Karanganyar, 2016).

Populasi penelitian ini adalah seluruh anggota kelompok tani yang menjadi penerima program Unit Pengolah Pupuk Organik (UPPO) di enam desa, lima kecamatan di Kabupaten Karanganyar yakni Desa Pereng, Desa Pendem (Kecamatan Mojogedang); Desa Seloromo (Kecamatan Jenawi); Desa Ngeblak (Kecamatan Tawangmangu); Desa Kerjo (Kecamatan Kerjo); dan Desa Ngadiluwih (Kecamatan Matesih) dengan jumlah sampel sebanyak 60 petani. Pengambilan sampel menggunakan proportional random sampling (Slamet, 2011). Penelitian ini menggunakan jenis data kuantitatif dan kualitatif, sedangkan sumber data yang digunakan dalam penelitian ini adalah sumber data primer dan sekunder. Pengumpulan data dalam penelitian ini diperoleh dengan menggunakan teknik observasi, wawancara, pencatatan dan dokumentasi.

Pengujian kuesioner menggunakan uji validitas dan uji reliabilitas dengan bantuan program IBM SPSS 22. Uji validitas menggunakan korelasi pearson yang dilakukan terhadap 60 responden dengan hasil 68 pernyataan variabel $\mathrm{x}$ dan 28 pernyataan variabel y dinyatakan valid. Hasil yang diperoleh dari nilai cronbach alpha adalah 0,815 dimana reliabilitas instrumen dari 96 pernyataan dinyatakan memiliki validitas yang sangat tinggi. Analisis data untuk mengetahui partisipasi petani, umur, pengalaman individu, pendidikan nonformal, akses informasi dan pengambilan risiko petani dalam kegiatan Unit Pengolah Pupuk Organik (UPPO) menggunakan rumus lebar interval yang dikategorikan menjadi 4 skor yakni sangat tinggi, tinggi, rendah, sangat rendah.

Analisis data untuk mengetahui hubungan antara umur, pengalaman individu, pendidikan nonformal, akses informasi dan pengambilan 
risiko petani dalam program Unit Pengolah Pupuk Organik (UPPO) menggunakan analisis korelasi rank spearman (rs). Untuk menguji tingkat signifikansi hubungan digunakan perbandingan nilai Sig (2-tailed) dengan tingkat kepercayaan $95 \%$, kesalahan yang ditoleransi $(\alpha=0,05)$ (Suliyanto, 2011). Kriteria pengambilan keputusan yakni, jika nilai Sig. (2-tailed) $\leq a=0,05$, maka Ho ditolak dan $\mathrm{H}_{1}$ diterima, yang berarti terdapat hubungan yang signifikan antara umur, pengalaman individu, pendidikan nonformal, akses informasi dan pengambilan risiko petani dengan partisipasi petani dalam kegiatan UPPO. Jika nilai Sig. (2-tailed) $>a=0,05$, maka Ho diterima dan $\mathrm{H}_{1}$ ditolak, yang berarti tidak terdapat hubungan yang signifikan antara umur, pengalaman individu, pendidikan nonformal, akses informasi dan pengambilan risiko petani dengan partisipasi petani dalam kegiatan UPPO.

\section{HASIL DAN PEMBAHASAN}

\section{Partisipasi Petani dalam Kegiatan Unit Pengolah Pupuk Organik (UPPO) di Kabupaten Karanganyar}

Menurut Adisasmita (2013), partisipasi adalah keterlibatan anggota masyarakat dalam pembangunan meliputi kegiatan dalam perencanaan dan pelaksanaan program pembangunan yang dilakukan masyarakat lokal. Keterlibatan dan keikutsertaan tersebut dilakukan sebagai akibat dari terjadinya interaksi sosial antara individu yang bersangkutan dengan anggota masyarakat yang lain. Tingkat partisipasi petani yang dimaksud dalam penelitian ini adalah frekuensi keterlibatan dan keikutsertaan petani dalam kegiatan UPPO yang dilihat dari tahap perencanaan, pelaksanaan, dan pemanfaatan hasil. Berikut distribusi responden berdasarkan Partisipasi Petani dalam Kegiatan UPPO di Kabupaten Karanganyar dapat dilihat pada Tabel 1.

Tabel 1. Partisipasi Petani dalam Kegiatan UPPO di Kabupaten Karanganyar

\begin{tabular}{lcr}
\hline Kategori & Responden (orang) & Persentase (\%) \\
\hline Sangat tinggi & 14 & 23,33 \\
Tiinggi & 28 & 46,67 \\
Rendah & 16 & 36,67 \\
Sangat rendah & 2 & 3,33 \\
\hline
\end{tabular}

Sumber: Olahan Data Primer, 2019

Partisipasi petani dalam kegiatan UPPO di Kabupaten Karanganyar ini termasuk kategori tinggi dimana petani antusias untuk menjalankan kegiatan dari pemerintah untuk mendukung kesejahteraan petani di Kabupaten Karanganyar. Kawasan yang sangat berpotensi dalam bidang pertanian ini menjadi peluang untuk petani dalam mencukupi kebutuhan sehari-hari. Dukungan pemerintah dengan menghadirkan program-program pertanian seperti UPPO ini menjadi tantangan petani dalam mengelola dan menjalankan program dengan baik sehingga, apabila program tersebut berjalan dengan baik dan berkelanjutan petani mendapat keuntungan dan manfaat, terlebih Kabupaten Karanganyar menjadi kawasan perdesaan organik dimana partisipasi petani dalam menerapkan pertanian organik sangatlah penting. Partisipasi petani dalam kegiatan UPPO berdasarkan tiga tahapan yakni perencanaan, pelaksanaan dan pemanfaatan hasil.

Tabel 2. Tahapan Partisipasi Petani dalam Kegiatan UPPO di Kabupaten Karanganyar

\begin{tabular}{lccr}
\hline Tahapan Partisipasi Petani & Kategori & Responden (orang) & Persentase (\%) \\
\hline 1. Perencanaan & Rendah & 36 & 60,00 \\
2. Pelaksanaan & Tiinggi & 27 & 45,00 \\
3. Pemanfaatan Hasil & Tinggi & 34 & 56,67 \\
\hline
\end{tabular}

Sumber: Olahan Data Primer, 2019 
Partisipasi petani pada tahap perencanaan adalah keterlibatan petani dalam menyusun rencana kegiatan UPPO dengan melibatkan sumber daya yang dimiliki. Partisipasi pada tahap perencanaan tersebut terdiri dari intensitas keterlibatan petani mengajukan gagasan terkait rencana kegiatan, terlibat dalam penentuan jadwal kegiatan, serta terlibat dalam penyusunan Rencana Usaha Kegiatan (RUK) mengenai pembiayaan sesuai kondisi kebutuhan lapang. Hasil dilapang menunjukkan bahwa tingkat partisipasi petani termasuk dalam golongan rendah pada tahap perencanaan. Sebenarnya, gagasan yang diajukan dari para petani pada saat pertemuan sangat penting karena gagasan tersebut dapat menjadi pelengkap hal-hal yang kurang dan yang perlu ditambahkan untuk menyempurnakan kegiatan UPPO. Namun, terdapat petani yang enggan untuk mengajukan gagasan dan petani hanya mengikuti orang yang mereka anggap lebih tahu atau yang lebih berpengalaman.

Partisipasi petani pada tahap pelaksanaan adalah keikutsertaan petani dalam melaksanakan dan memberikan kontribusi dalam pemanfaatan UPPO. Partisipasi pada tahap pelaksanaan tersebut terdiri dari intensitas petani dalam menyumbangkan tenaga pada seluruh rangkaian UPPO yang terdiri dari pembangunan rumah kompos dan bak fermentasi, pembangunan kandang komunal, pegadaan ternak, pengadaan alat pengolah pupuk organik, dan pengadaan alat angkut kendaraan roda tiga. Selain itu partisipasi petani pada tahap pelaksanaan juga intensitas petani dalam megikuti pertemuan kelompok untuk mengidentifikasi kendala dan masalah yang terjadi selama kegiatan berlangsung. Hasil dilapang menunjukkan bahwa tingkat partisipasi petani termasuk dalam golongan tinggi pada tahap pelaksanaan. Petani terlibat dalam pelaksanaan kegiatan dikarenakan petani merasa menjadi bagian dari kegiatan ini sehingga memiliki rasa tanggungjawab untuk berpartisipasi dalam keberlangsungan UPPO.

Partisipasi petani pada tahap pemanfaatan hasil adalah keterlibatan petani dalam merasakan manfaat dari adanya kegiatan UPPO. Partisipasi pada tahap pemanfaatan hasil tersebut terdiri dari seberapa petani merasakan manfaat setelah menjalankan UPPO seperti dengan adanya UPPO kebutuhan pupuk organik dapat tercukupi secara insitu dimana petani tidak perlu mencari pupuk dari luar wilayah mereka. Hasil dilapang menunjukkan bahwa tingkat partisipasi petani termasuk dalam golongan tinggi pada tahap pemanfaatan hasil. Petani terlibat dalam merasakan manfaat dari UPPO ini dikarenakan dengan adanya kegiatan tersebut petani dapat menerapkan pertanian organik di setiap wilayah khususnya yang menjalankan UPPO guna mendukung Kabupaten Karanganyar menjadi kawasan perdesaan organik.

2. Umur, Pengalaman Individu, Pendidikan Nonformal, Akses Informasi dan Pengambilan Risiko Petani dalam Kegiatan Unit Pengolah Pupuk Organik (UPPO) di Kabupaten Karanganyar.

Menurut Slamet (1993), faktor yang berhubungan dengan partisipasi yaitu umur, pendidikan, pendapatan, dan jenis pekerjaan. Menurut Ife (2008), faktor yang kondusif bagi partisipasi dan yang mewakili sumber daya positif bagi masyarakat yakni pengetahuan dan pemahaman, akses informasi, pelatihan masyarakat lokal dan kontrol masyarakat lokal. Dalam penelitian ini, faktor yang berhubungan dengan partisipasi yakni umur, pengalaman individu, pendidikan nonformal, akses informasi dan pengambilan risiko.

Tabel 3. Faktor-Faktor yang Berhubungan dengan Partisipasi Petani dalam Kegiatan UPPO di Kabupaten Karanganyar

\begin{tabular}{lccr}
\hline Faktor-Faktor Partisipasi & Kategori & Responden (orang) & Persentase (\%) \\
\hline Umur & Produktif & 55 & 91,67 \\
Pengalaman Individu & Tinggi & 33 & 55,00 \\
Pendidikan Nonformal & Tinggi & 30 & 50,00 \\
Akses Informasi & Rendah & 29 & 48,33 \\
Pengambilan Risiko & Siap & 42 & 70,00 \\
\hline
\end{tabular}

Sumber: Olahan Data Primer, 2019 
Umur dapat mempengaruhi petani dalam merespons suatu informasi atau inovasi yang diterimanya. Petani di Kabupaten Karanganyar yang menjalankan kegiatan UPPO didominasi oleh petani yang berumur 35-49 tahun. Umur petani mempengaruhi kondisi petani dalam melakukan aktivitas, khususnya aktifitas fisik, terutama pada kegiatan pertanian yang membutuhkan tenaga cukup besar. Semakin petani menjauhi usia produktif maka semakin menurun kemampuan petani semakin menurun. Petani yang memiliki umur produktif mempunyai kemampuan fisik yang kuat untuk menjalankan kegiatan dan mengembangkan usahataninya. Petani dengan usia produktif lebih mudah dan lebih terbuka dalam menerima suatu inovasi terkait pengembangan pertanian khususnya pertanian organik.

Pengalaman individu dilihat berdasarkan pengetahuan, informasi, dan peristiwa yang pernah dihadapi dan dirasakan oleh petani terkait dengan proses pemupukan dilahan usahatani. Petani megetahui dalam penerapan pupuk organik, penggunaan pupuk organik, proses pembuatan pupuk organik dan kemudahan dalam mendapatkan pupuk organik. Petani mulai beralih pada pertanian organik karena hasil panen dari pertanian organik dirasa dapat meningkatkan kas kelompok tani dengan harga jual yang lebih mahal (Rp. 12.000,00 Rp. $13.000,00 / \mathrm{kg}$ ) dari pertanian non organik (Rp.9000,00 - Rp.11.000,00/kg) meskipun untuk hasil panen tidak meningkat secara drastis, tetapi dengan harga jual yang tinggi maka, petani dapat merasakan keuntungan setelah menerapkan pupuk organik di lahan usahatani.

Pendidikan nonformal dilihat berdasarkan tingkat pendidikan yang diperoleh petani melalui jalur pendidikan diluar pendidikan nonformal yang dapat dilaksanakan secara berstruktur dan berjenjang. Pendidikan nonformal, dilaksanakan melalui sosialisasi, penyuluhan dan pelatihan. petani sering mengikuti sosialisasi kegiatan Unit Pengolah Pupuk Organik (UPPO) baik sosialisasi dari Dinas Pertanian atau penyuluh. Sosialisasi dilaksanakan lebih dari 6 kali per tahun, penyuluhan dilaksanakan selama 12 kali per tahun, pelatihan UPPO dari Dinas Pertanian atau penyuluh dilaksanakan selama 4 kali per tahun.
Akses informasi ditunjukkan dalam kemudahan petani dalam mengakses informasi mengenai UPPO. Sumber informasi didapatkan dari penyuluh pertanian dan Dinas Pertanian, dimana akses informasi mengenai UPPO dikatakan rendah karena petani lebih banyak mendapatkan informasi dari Dinas Pertanian saja dibandingkan dengan penyuluh pertanian. Petani sulit dalam mengakses informasi mengenai pengadaan ternak. Dimana hal tersebut disebabkan oleh kurangnya interaksi penyuluh pertanian ke kelompok-kelompok tani yang menjalankan UPPO. Selain itu, petani juga lebih berkomunikasi dengan Dinas Pertanian secara langsung, karena Dinas Pertanian lebih sering mengadakan monitoring keberjalanan UPPO secara langsung dan rutin.

Pengambilan risiko petani ditunjukkan dengan kesiapan petani dalam kegagalan UPPO, kerusakan rumah kompos, kerusakan kandang komunal, kematian ternak, kerusakan alat pengolah pupuk organik dan kerusakan alat pengangkut dan kendaraan roda tiga. Petani sangat siap dan siap mengambil risiko apabila UPPO gagal dan terdapat kerusakan pada rumah kompos dan bak fermentasi, kematian ternak, kandang komunal, alat pengolah pupuk organik, serta alat angkut kendaraan roda tiga karena petani merasa bahwa kegiatan tersebut adalah kegiatan yang dijalankan oleh kelompok sehingga apapun keadaannya petani siap mengambil risiko secara bersama-sama.

\section{Hubungan antara Umur, Pengalaman Individu, Pendidikan Nonformal, Akses Informasi dan Pengambilan Risiko Petani dengan Partisipasi Petani dalam Kegiatan Unit Pengolah Pupuk Organik (UPPO) di Kabupaten Karanganyar.}

Dari beberapa variabel yang dikaji terlihat variabel yang berhubungan sangat signifikan yakni pengalaman individu, akses informasi, dan pengambilan risiko petani. Hubungan antara faktor-faktor petani dengan partisipasi petani dalam kegiatan ini dapat diketahui dengan menggunakan uji korelasi rank spearman $\left(r_{s}\right)$ yang perhitungannya menggunakan program IBM SPSS 22. Hasil analisis korelasi Rank Spearman $\left(r_{s}\right)$ terlihat pada Tabel 4 berikut ini: 
Tabel 4 Uji Statistik Hubungan antara Umur, Pengalaman Individu, Pendidikan Nonformal, Akses Informasi dan Pengambilan Risiko Petani dengan Partisipasi Petani

\begin{tabular}{llcr}
\hline \multirow{2}{*}{$\begin{array}{l}\text { Faktor-faktor yang Berhubungan } \\
\text { dengan Partisipasi (X) }\end{array}$} & \multicolumn{3}{c}{$\begin{array}{c}\text { Partisipasi Petani dalam Kegiatan Unit Pengolah } \\
\text { Pupuk Organik (UPPO) (Y) }\end{array}$} \\
\cline { 2 - 4 } & $\mathbf{r}_{\mathrm{s}}$ & Sig. (2-tailed) & Keterangan \\
\hline Umur (X1) & 0,110 & 0,402 & Tidak signifikan \\
Pengalaman Individu (X2) & $0,344^{* *}$ & 0,007 & Sangat signifikan \\
Pendidikan Nonformal (X3) & 0,113 & 0,391 & Tidak signifikan \\
Akses Informasi (X4) & $0,446^{* *}$ & 0,000 & Sangat signifikan \\
Pengambilan Risiko (X5) & $0,369^{* *}$ & 0,004 & Sangat signifikan \\
\hline
\end{tabular}

Sumber: Analisis Data Primer, 2019

Nilai $r_{s}$ umur yaitu sebesar 0,110 pada $\alpha=$ 0,05 dengan Sig. (2-tailed) sebesar 0,402 dan $\alpha$ sebesar 0,05 sehingga dapat dilihat bahwa nilai Sig. (2-tailed) $(0,402)>\alpha(0,05)$, maka $\mathrm{H}_{0}$ diterima dan $\mathrm{H}_{1}$ ditolak. Hal ini bermakna tidak terdapat hubungan yang signifikan antara umur petani dengan partisipasi petani dalam kegiatan UPPO di Kabupaten Karanganyar dengan tingkat kepercayaan 95\%. Hal ini menunjukkan bahwa seberapa usia tua atau usia muda tidak berhubungan dengan partisipasi. Menurut Slamet (1993), semakin tua usia semakin aktif dalam berpartisipasi, petani usia muda cenderung menjadi anggota, dan petani usia tua terlibat aktif dalam berpartisipasi. Kenyataan di lapangan tua ataupun muda umur petani tidak berhubungan dengan tingkat pastisipasinya dalam menjalankan dan mengelola kegiatan UPPO baik dalam tahap perencanaan, pelaksanaan, dan pemanfaatan hasil. Hal ini dikarenakan semua anggota kelompok tani merasa memiliki tanggung jawab sebagai pelaku untuk menjalankan UPPO, dimana kegiatan tersebut memberikan manfaat dan keuntungan yang besar bagi kelompok tani, hal ini ditunjukkan dengan meningkatkatnya kas kelompok tani karena harga jual beras organik tinggi, dan hasil penjualan produksi pupuk organik sendiri serta pengeluaran untuk pengelolaan UPPO di beri modal oleh pemerintah. Keuntungan yang telah dirasakan, membuat petani semangat untuk terus mengelola dan menjaga kegiatan tanpa pandang umur tua ataupun muda.
Nilai $r_{s}$ pengalaman individu yaitu sebesar 0,344 pada $\alpha=0,05$ dengan dengan Sig. (2-tailed) sebesar 0,007 dan $\alpha$ sebesar 0,05 sehingga dapat dilihat bahwa Sig. (2-tailed) $(0,007)<\alpha(0,05)$, maka $\mathrm{H}_{0}$ ditolak dan $\mathrm{H}_{1}$ diterima. Hal ini bermakna terdapat hubungan yang sangat signifikan antara pengalaman individu dengan partisipasi petani dalam kegiatan UPPO di Kabupaten Karanganyar dengan tingkat kepercayaan 95\%. Hubungan yang sangat signifikan ini dapat terjadi karena petani yang memiliki pengalaman lebih lama dalam proses pemupukan organik dilahan usahatani akan sangat berpengalaman dibidang pengelolaan pertanian organik. Menurut Azwar (2002), individu sebagai orang yang menerima pengalaman, orang yang melakukan tanggapan atau penghayatan, biasanya tidak melepaskan pengalaman yang sedang dialaminya dari pengalaman-pengalaman lain yang terdahulu, yang relevan. Dalam hal ini, pengalaman petani dalam menggunakan pupuk organik dilahan usahatani sangat diperhatikan, karena dalam proses penerapan pertanian organik dibutuhkan individu yang ulet, teliti, dan sabar dalam mengelola lahan usahatani organik dimana dalam penerapannya terdapat banyak kendala salah satunya menurunnya hasil panen. Penggunaan pupuk organik untuk tanaman, dalam pertumbuhannya tidaklah cepat dan menghasilkan panen yang tinggi seperti penggunaan pupuk kimia akan tetapi, penggunaan pupuk organik dilahan usahatani ini dapat menyuburkan tanah sehingga hasil 
panen juga berkualitas dan dijual dengan harga yang lebih tinggi dibandingkan hasil panen yang menggunakan pupuk kimia.

Nilai $r_{s}$ pendidikan nonformal yaitu sebesar 0,113 pada $\alpha=0,05$ dengan Sig.(2-tailed) sebesar 0,391 sehingga dapat dilihat bahwa Sig. (2-tailed) $(0,391)>\alpha(0.05)$, maka $\mathrm{H}_{0}$ diterima dan $\mathrm{H}_{1}$ ditolak. Hal ini bermakna tidak terdapat hubungan yang signifikan antara pendidikan nonformal dengan partisipasi petani dalam kegiatan UPPO di Kabupaten Karanganyar dengan tingkat kepercayaan 95\%. Hal ini menunjukkan bahwa keikutsertaan petani dalam sosialisasi, penyuluhan dan pelatihan tidak berhubungan dengan partisipasi baik dalam tahap perencanaan, pelaksanaan dan pelatihan. Petani yang mengikuti atau tidak mengikuti sosialisasi, penyuluhan maupun pelatihan akan tetap berpartisipasi dalam kegiatan ini karena mereka memiliki rasa tanggung jawab kebersamaan akan keberjalanan kegiatan, alasan mereka tidak mengikuti pendidikan nonformal tersebut adalah karena mereka membagi waktu dengan pekerjaan lain (selain petani). Menurut peraturan pemerintah Republik Indonesia nomor 17 tahun 2010, pendidikan nonformal adalah jalur pendidikan diluar jalur pendidikan formal yang dilaksanakan secara terstruktur dan berjenjang. Adanya sosialisasi, penyuluhan dan latihan membuat petani dapat menambah informasi mengenai kegiatan yang sedang dijalankan. Petani harus aktif dalam mengikuti penyuluhan-penyuluhan sehingga penerapan teknologi atau hal baru dapat meluas dan berkembang. Kenyataan di lapang, pendidikan nonformal melalui sosialisasi sering dilakukan untuk memberikan pengarahan awal kegiatan kepada kelompok tani, agar petani mengerti dan memahami tujuan dari UPPO. Petani jarang mengikuti penyuluhan, sehingga tidak banyak petani yang mengetahui secara detail mengenai UPPO antara lain mengenai standar operasional ataupun aturan yang terdapat pada kegiatan. Petani sering ikut serta dalam pelatihan, yang meliputi pelatihan pembuatan rumah kompos dan bak fermentasi, pembuatan kandang komunal, pembuatan fermentasi pupuk, serta pelatihan mengoperasikan alat pengolah pupuk organik karena petani merasa pelatihan penting mengetahui standar serangkaian kegiatan agar berjalan sesuai dengan rencana kegiatan UPPO.
Nilai $r_{s}$ akses informasi yaitu sebesar 0,446 pada $\alpha=0,05$ dengan Sig.(2-tailed)0,000 sehingga dapat dilihat bahwa Sig.(2-tailed) $(0,000)<\alpha(0,05)$, maka $\mathrm{H}_{0}$ ditolak dan $\mathrm{H}_{1}$ diterima. Hal ini bermakna terdapat hubungan yang sangat signifikan antara akses informasi dengan partisipasi petani partisipasi petani dalam kegiatan UPPO di Kabupaten Karanganyar dengan tingkat kepercayaan $95 \%$. Hubungan yang sangat signifikan ini dapat terjadi karena kemudahan petani dalam mengakses informasi mengenai serangkaian UPPO yang terdiri dari pembangunan rumah kompos dan bak fermentasi, pembangunan kandang komunal, pengadaan ternak, pengadaan alat pengolah pupuk organik, pengadaan alat angkut kendaraan roda tiga. Setiap petani yang berpartisipasi dapat memberikan informasi yang baik dan berguna yang nantinya akan bermanfaat dalam keberlanjutan program (Sujana, 2010). Petani mudah memahami dan terlibat langsung dalam UPPO setelah mencari informasi mengenai kegiatan tersebut. Semakin mudah petani dalam mengakses informasi mengenai UPPO maka petani semakin berpartisipasi dalam berlangsungnya UPPO. Petani tertarik untuk menjalankan kegiatan tersebut karena mereka mendapat informasi mengenai manfaat dan keuntungan menjalankan kegiatan ini salah satunya meningkatkan kas kelompok serta pendapatan petani pula.

Nilai $r_{s}$ pengambilan risiko yaitu sebesar 0,369 pada $\alpha=0,05$ dengan Sig.(2-tailed) sebesar 0,004 sehingga dapat dilihat bahwa Sig.(2-tailed) $(0,004)<\alpha(0,005)$, maka $\mathrm{H}_{0}$ ditolak dan $\mathrm{H}_{1}$ diterima. Hal ini bermakna terdapat hubungan yang sangat signifikan antara pengambilan risiko dengan partisipasi petani dalam kegiatan UPPO di Kabupaten Karanganyar dengan tingkat kepercayaan 95\%. Semakin berani petani mengambil risiko, semakin tinggi pula partisipasinya dalam menjalankan serangkaian UPPO. Petani penting untuk berani mengambil risiko karena menurut Nelson (1978) Pengambilan risiko penting karena hampir setiap hari petanipetani dihadapkan pada kondisi usahatani dan untuk pertanian organik hasil panen yang tidak pasti bahkan menurun. Kenyataan di lapangan pengambilan risiko petani termasuk dalam 
kategori tinggi, dimana petani siap mengambil risiko jika UPPO gagal baik dalam tahap perencanaan, pelaksanaan, dan pemanfaatan hasil, yang meliputi kerusakan-kerusakan pada rumah kompos dan bak fermentasi, kandang komunal, alat pengolah pupuk organik, alat angkut kendaraan roda tiga dan kematian ternak. Semakin berani petani mengambil risiko dari usahatnai makasemakin tinggi pula partisipasinya pada tahap pelaksanaan. Petani yang memberanikan diri untuk mengambil risiko dapat meningkatkan semangat untuk melaksanakan kegiatan, sehingga petani tersebut akan semakin aktif. Kesiapan petani dalam mengambil risiko tersebut karena petani merasa UPPO ini adalah tanggung jawab bersama kelompok yang harus dijalankan bersama-sama.

\section{KESIMPULAN DAN SARAN}

\section{Kesimpulan}

Partisipasi petani responden dalam kegiatan Unit Pengolah Pupuk Organik (UPPO) di Kabupaten Karanganyar termasuk dalam kategori tinggi. Analisis tingkat partisipasi petani dalam pemanfaatan UPPO berdasarkan tahapan partisipasi yakni; pada tahap perencanaan dalam kegiatan UPPO termasuk dalam kategori rendah, pada tahap pelaksanaan dalam kegiatan UPPO termasuk dalam kategori tinggi, dan pada tahap pemanfaatan hasil dalam kegiatan UPPO termasuk dalam kategori tinggi. Umur petani responden dalam kegiatan UPPO termasuk dalam kategori produktif. Pengalaman individu petani dalam menjalankan kegiatan UPPO termasuk dalam kategori tinggi. Pendidikan nonformal petani responden termasuk dalam kategori tinggi dalam kegiatan UPPO. Akses informasi mengenai kegiatan UPPO termasuk dalam kategori rendah. Pengambilan resiko petani responden terhadap kegagalan program atau keadaan yang tidak di inginkan termasuk dalam kategori siap.

Tidak terdapat hubungan yang signifikan antara umur dengan partisipasi petani responden dalam kegiatan UPPO. Terdapat hubungan yang sangat signifikan antara pengalaman individu dengan partisipasi petani responden dalam kegiatan UPPO. Semakin petani berpengalaman dalam menerapkan pertanian organik, maka semakin tinggi partisipasinya dalam menjalankan kegiatan. Tidak terdapat hubungan yang signifikan antara pendidikan nonformal dengan partisipasi petani responden dalam kegiatan UPPO. Terdapat hubungan yang sangat signifikan antara akses informasi dengan partisipasi petani responden dalam kegiatan UPPO. Semakin mudah petani mengakses informasi, semakin tinggi partisipasinya dalam menjalankan kegiatan. Terdapat hubungan yang sangat signifikan antara pengambilan resiko dengan partisipasi petani responden dalam kegiatan UPPO. Semakin siap petani mengambil risiko, maka semakin tinggi partisipasinya dalam menjalankan kegiatan.

\section{Saran}

Bagi Pemerintah dianjurkan untuk adanya peningkatan interaksi melalui sosialisasi, penyuluhan dan pelatihan baik dari Dinas Pertanian atau penyuluh yang memberikan informasi dan pengertian bahwa kegiatan tersebut merupakan kegiatan bersama kelompok dimana setiap anggota kelompok tani memiliki tanggung jawab untuk ikut serta dalam keberjalanan kegiatan UPPO. Selain untuk kebersamaan seluruh anggota kelompok tani dan pengurus kelompok harus dieratkan agar tidak terjadi kesenjangan antar satu sama lain. Pemerintah juga perlu memberikan pengalaman-pengalaman yang baik seperti, pelatihan dan pendampingan kepada petani sehingga proses kegiatan UPPO memberikan keluaran sesuai yang diharapkan. Bagi penyuluh pertanian dianjurkan untuk lebih meningkatkan komunikasi dengan kelompok tani khususnya yang menjalankan kegiatan UPPO, dimana peran penyuluh adalah sebagai fasilitator dan sangat diperlukan pendampingan keberjalanan kegiatan agar petani dapat melaksanakan kegiatan sesuai prosedur yang ada dalam petunjuk teknis kegiatan. Bagi petani diharapkan dapat menjaga dan mempertahankan kegiatan yang telah dijalankan dan juga perlu adanya perkembangan seperti peningkatan pemasaran produksi pertanian organik, petani juga harus selalu bekerja sama dalam menjalankan kegiatan ini karena UPPO dirasa memberikan keuntungan bagi kelompok tani sehingga, partisipasi petani dan kebersamaan kelompok penting dalam mendukung keberjalanan program UPPO guna mewujudkan kesejahteraan petani yang berkelanjutan. 


\section{DAFTAR PUSTAKA}

Adisasmita, R. 2010. Pembiayaan Pembangunan Daerah. Jakarta : Graha Ilmu

Azwar. 2002. Sikap Manusia Edisi II. Yogyakarta: Pustaka Belajar

Bachtiar R, Hernanto. 1991. Ilmu Usahatani. Jakarta : Penebar Swadaya.

Bappenas. 2007. Partisipasi Masyarakat. www. air.bappenas.go.id. Diakses Tanggal 23 Mei 2019 Pukul 13.00 WIB.

Basrowi. 2014. Pengantar Sosiologi. Bogor: Ghalia Indonesia.

Debertin, D.L. 1986. Agricultural Production Economics.New York :Macmillan Publishing Company.

Dirjen Tanaman Pangan. 2018. http:// tanamanpangan.pertanian.go.id/. Diakses 26 Mei 2019

Haqqie, Shahnaz NY. 2016. Partisipasi Masyarakat dalam Program Pemberdayaan (Studi Kasus Kegiatan Pembuatan Pupuk Organic di Desa Blagung, Boyolali).Semarang : Universitas Negeri Semarang.

http://rpkp.org/kab-karanganyar/\#150699456018992ea2974-f088. Diakses pada tanggal 18 Februari 2019.

Ife, J dan Tesoriero, F. 2008. Alternatif Pengembangan Masyarakat di Era Globalisasi.Yogyakarta : Pustaka Pelajar

Joesoef, Soelaiman. 2008. Konsep Dasar Pendidikan Luar Sekolah. Jakarta: PT Bumi Aksara.

Kementerian Pertanian. 2011. Pedoman Unit Pengolah Pupuk Organik. www.kementan. go.id. Diakses tanggal Tanggal 23 Mei 2019 Pukul 13.00 WIB.

Keputusan Bupati. Nomor: 050/727 Tahun 2016. Kawasan Perdesaan Organik di Lereng Gunung Lawu.
Molo E, Gavagnin M, Carbone M, Castelluccio F, Pozone F, Roussis V,Templado J, Ghiselin TM, Cimino G. 2008. Factors promoting marineinvasions: A chemoecologycal approach. PNAS Vol 105 No 12:4582-4586

Nelson, P. 1978. Greenhouse : Operation and Management. Virginia : Reston Publishing Company, Inc

Peraturan Menteri Pertanian Nomor 64/Permentan/ Ot.140/5/2013 Tentang Sistem Pertanian Organik

Prawoto A. and Surono I. 2005. Organic Agriculture in Indonesia: A Wannabe Big Player in the Organic World, http://eng. biocert.or.id/ artikel isi.php?aid=73 (Diakses pada 21 Maret 2019).

Shannon M, Oltmann. 2010. "Information Access", di bawah "settings", http://bpm. ils.indiana.edu/scholarship/oltmann_paper. $p d f$ (diakses pada 28 Agustus 2019)

Slamet, Y. 1993. Pembangunan Masyarakat Berwawasan Partisipasi. Surakarta : Sebelas Maret University Press.

Sugiyono. 2014. Metode Penelitian Kuantitatif, Kualitatif, dan R\&D. Bandung: Penerbit Alfabeta

Sujana, D. 2004. Pendidikan Non Formal. Bandung : Fallah Production

Sulaeman, A. 2014.Pengaruh Upah dan Pengalaman Kerja terhadap Produktivitas Karyawan Kerajinan Ukiran Kabupaten Subang, Trikonomika Vol 13 No 1, (91100).

Suliyanto. 2011. Ekonometrika Terapan: Teori dan Aplikasi Dengan SPSS. Edisi 1. Yogyakarta: Andi Yogyakarta

Undang-Undang Nomor 32. 2009. Perlindungan Dan Pengelolaan Lingkungan Hidup 